\title{
The Tale of Two Men: Testimonial Styles in the Presentation of Asylum Claims
}

\author{
Forough Ramezankhah*
}

\begin{abstract}
In determining refugee status, the credibility of an asylum seeker is significantly influenced by the way he or she presents the claim. In the United Kingdom, as elsewhere, the initial decision makers place great emphasis on a detailed, consistent, and plausible account as an indicator of credibility. There is evidence that socio-economic background and education may affect witnesses’ testimonial styles. However, in the context of asylum, most research has shied away from investigating other factors that influence testimonial styles and how claims are presented. In addition, there has never been a comparison of the presentational skills of two asylum seekers, with similar backgrounds, personal characteristics, and claims, in order to explore how these skills impact on the success of their claims. Drawing on a range of disciplines and empirical data from selected Free Association Narrative Interviews, this article compares two asylum seekers with similar attributes and similar asylum grounds, whose presentational skills were found to be significantly dissimilar. The findings are based on analysis of their interview data, which provided insights into how their asylum testimonies may have been presented. The UNHCR Handbook, which sets out guidelines for determining refugee status, highlights that it is not the duty of an asylum seeker to analyse his or her case to such an extent as to identify the reasons for persecution in detail. In light of this, the article challenges the assumption and expectation that asylum seekers can be left to their own devices to present a detailed and consistent claim. It concludes that, if individuals possess different presentational skills that may affect the outcome of their claims, then asylum seekers deficient in such skills should be supported by prior familiarization with the asylum process.
\end{abstract}




\section{INTRODUCTION}

Refugee status determination may not merely involve an assessment of the applicant's credibility, but may be as much about testimonial style and presentation. ${ }^{1}$ There is evidence that asylum seekers who are able to employ a testimonial style that is 'acceptable' to decision makers may be viewed as more credible, whereas those who are unfamiliar with the style may be misconstrued and vulnerable to refusal. ${ }^{2}$ Although it has been implicitly known that testimonial styles can affect the outcome of claims, there has been no previous empirical study focusing on a comparative analysis of asylum seekers’ presentational skills.

The purpose of this article is to examine the testimonial styles of two asylum seekers with similar characteristics: age, education, family background. These individuals presented their accounts in very different ways, which may have affected the outcomes of their asylum claims. The article analyses data from the interviews of two men who were participants in a much larger study, ${ }^{3}$ which investigated narrative construction by Iranian asylum seekers in the context of their asylum claims, and how highly personal experiences must be displayed on the legal stage in a bid for international protection. The analysis of data for the larger study was influenced by psychosocial enquiry. ${ }^{4}$

The article comprises five main sections. Part 2 outlines the non-legal factors that may affect an applicant's credibility, while part 3 focuses on the legal framework and examines the difficulties related to specific guidelines issued by the United Nations High

* Dr Forough Ramezankhah is a Teaching Fellow at Keele University, UK. The author would like to thank Professor Fiona Cownie, Dr Yvonne Griffiths, and the anonymous reviewers for the International Journal of Refugee Law.

1 Robert F Barsky, Constructing a Productive Other: Discourse Theory and the Convention Refugee Hearing (John Benjamins Publishing 1994) 119.

2 ibid.

3 Forough Ramezankhah, 'Asylum Stories: A Socio-Legal Study of Iranian Claims for Asylum in the UK' (PhD thesis, Keele University 2013).

4 David Gadd, 'In-Depth Interviewing and Psychosocial Case Study Analysis’ in David Gadd, Susanne Karstedt, and Steven F Messner (eds), The SAGE Handbook of Criminological Research Methods (Sage 2012). 
Commissioner for Refugees ${ }^{5}$ (UNHCR) and United Kingdom (UK) authorities. Parts 4 and 5 describe the study's methodology and data analysis respectively. Finally, the article presents its conclusions.

\section{NON-LEGAL FACTORS AFFECTING CREDIBILITY}

Asylum seekers face a number of challenges in presenting their protection claims. ${ }^{6}$ The UNHCR Handbook highlights the many challenges faced by an applicant for refugee status, including linguistic difficulties.

[A]n applicant for refugee status is normally in a particularly vulnerable situation. He finds himself in an alien environment and may experience serious difficulties, technical and psychological, in submitting his case to the authorities of a foreign country, often in a language not his own. His application should therefore be examined within the framework of specially established procedures by qualified personnel having the necessary knowledge and experience, and an understanding of an applicant's particular difficulties and needs. ${ }^{7}$

The UNHCR Handbook thus recognizes that an asylum seeker may encounter a multitude of challenges in submitting a claim. In order to explore, highlight, and mitigate these difficulties, research on asylum seekers has engaged a number of disciplines, including, but not limited to, law, psychology, and linguistics.

Rather than analysing the challenges faced by asylum seekers in isolation, through the

5 United Nations High Commissioner for Refugees, Handbook and Guidelines on Procedures and Criteria for Determining Refugee Status under the 1951 Convention and the 1967 Protocol relating to the Status of Refugees (UNHCR Handbook) UN doc HCR/IP/4/Eng/Rev.1 (2nd edn, 1992) para 66.

$6 \quad$ The European Council on Refugees and Exiles (ECRE) notes that 'any refugee seeking protection is in a vulnerable position, but the ability of certain individuals to present an application for international protection is further impaired due to particular personal characteristics or especially traumatic experiences’: ECRE, ‘Right to Justice: Quality Legal Assistance for Unaccompanied Children - Comparative Report' (2014) fn 22, 11

7 UNHCR Handbook (n 5) para 190 (emphasis added). 
lens of one discipline, Rousseau and others provide a multidisciplinary approach to the process of refugee determination in Canada. They document the influences of legal, psychological, and cultural factors and observe that these three dimensions often impact negatively upon the decision maker's ability to assess claims and evaluate the credibility of applicants during hearings. They observe an inherent 'double bind' within the non-adversarial legal process whereby, on one hand, the applicant is exposed to the explicit assurance - 'We [the Canadian authorities] are here to protect you' - while, on the other hand, there is an implied assumption that the refugee is a liar. ${ }^{8}$ Confronted with these two irreconcilable messages, the applicant may abandon his or her own natural narrative style and endeavour to satisfy the expectations of the decision maker. As a result, applicants who are most familiar with the presentational style that is acceptable to decision makers tend to be viewed as more credible, whereas those who are unfamiliar with the style may be misconstrued and more vulnerable to refusal. ${ }^{9}$

In recent years, the disciplines of psychology and psychiatry have also contributed to explanations of and justifications for concealment, non-disclosure, discrepancies, and inconsistencies in the accounts of asylum seekers, which in law may lead to adverse credibility findings and be detrimental to the success of asylum claims. ${ }^{10}$ The psychological perspective argues for the importance of understanding the emotions involved in the process of seeking asylum, and suggests that many signs of apparent inconsistencies within a claim can be justified by the identification of trauma and its potentially negative impact on memory. ${ }^{11}$ These empirical studies suggest that there are many reasons why asylum seekers

8 Cécile Rousseau and others, 'The Complexity of Determining Refugeehood: A Multidisciplinary Analysis of the Decision Making Process of the Canadian Immigration and Refugee Board' (2002) 15 (1) Journal of Refugee Studies, 66

Cécile Rousseau, François Crépeau, Patricia Foxen, France Houle, 'The Complexity of Determining Refugeehood: A Multidisciplinary Analysis of the Decision-making Process of the Canadian Immigration and Refugee Board' (2002) 15 (1) Journal of Refugee Studies, 66.

9 Barsky (n 1).

10 Diana Bögner, Jane Herlihy, Chris R Brewin, 'Impact of Sexual Violence on Disclosure during Home Office Interviews’ (2007) 191 (1) The British Journal of Psychiatry, 75

11 Jane Herlihy, Peter Scragg, and Stuart Turner, 'Discrepancies in Autobiographical Memories Implications for the Assessment of Asylum Seekers: Repeated Interviews Study’ (2002) 7333 
are unwilling and/or unable to disclose certain parts of their claims to officials. They also suggest that these reasons stem primarily from psychological difficulties associated with fear of persecution, flight from home, and arrival in an alien legal and cultural environment. ${ }^{12}$ Herlihy, Gleeson, and Turner argue that immigration judges should take the psychological perspective into account in their assessment of credibility. ${ }^{13}$ This research highlights the psychological aspects of the persecution suffered in the country of origin and the subsequent stress experienced when attempting to present a claim for asylum in the host country.

There is evidence to suggest that the efficacy of memory should not be the critical factor in determining the credibility of the narrator. Psychological research on credibility indicates that memories are not complete or stable, and this is common to all individuals. ${ }^{14}$ In the context of refugee status determination, much research shows that the ability to remember events is marred by distortions and biases. Furthermore, there is a common assumption that if the applicant has really experienced persecution, then the retention and remembrance of it should be accurate and consistent. This is questionable. ${ }^{15}$

In addition to focusing on the mental state of asylum seekers, research suggests that the interaction between the examiner and asylum seeker is also highly significant. Herlihy

British Medical Journal 324; Jane Herlihy and Stuart Turner, 'Should Discrepant Accounts Given by Asylum Seekers Be Taken as Proof of Deceit?' (2006) 16 Torture: Quarterly Journal on Rehabilitation of Torture Victims and Prevention of Torture 81; Jane Herlihy and Stuart Turner, ‘Asylum Claims and Memory of Trauma: Sharing Our Knowledge’ (2007) 191 The British Journal of Psychiatry 3.

12 Stuart Turner and others, 'Mental Health of Kosovan Albanian Refugees in the UK' (2003) 182 The British Journal of Psychiatry 444; Diana Bögner, Chris Brewin, and Jane Herlihy, 'Refugees' Experiences of Home Office Interviews: A Qualitative Study on the Disclosure of Sensitive Personal Information’ (2010) 36 Journal of Ethnic and Migration Studies 519.

13 Jane Herlihy, Kate Gleeson, and Stuart Turner, 'What Assumptions about Human Behaviour Underlie Asylum Judgments?’ (2010) 22 International Journal of Refugee Law 351.

14 Hilary Evans Cameron, 'Refugee Status Determinations and the Limits of Memory’ (2010) 22 International Journal of Refugee Law 469.

15 Jane Herlihy, Laura Jobson, and Stuart Turner, 'Just Tell Us What Happened to You: Autobiographical Memory and Seeking Asylum’ (2012) 26 Applied Cognitive Psychology 661. 
and Turner have reviewed studies of 'suggestibility', showing that, in the course of any interview, not necessarily for an asylum claim, if the interviewer indicates that an interviewee's response is mistaken, or a question is repeated, suggesting that the first answer is not as expected, in light of negative feedback and/or leading questions, an interviewee may change his or her response. ${ }^{16}$ They argue that there is evidence that this general tendency particularly applies to asylum interviews, because of the vulnerability and low self-esteem that are typical characteristics of asylum seekers. ${ }^{17}$ It can be inferred that, given the power imbalance between the official and the asylum seeker as interviewee, and the insecurity and uncertainty created by explicit and/or implicit signs of the official's reluctance to believe testimony, ${ }^{18}$ the asylum seeker may follow these cues and attempt to counterbalance any negative feedback by reconstructing his or her account, potentially creating further inconsistencies that may undermine his or her credibility.

Consistency is one of the key credibility indicators, ${ }^{19}$ so it is crucial that the applicant is consistent when presenting his or her testimony. However, Cohen suggests that 'credibility assessment by the determination of the accuracy and reproducibility of an asylum seeker's recollection is not a valid component of asylum decision making'. ${ }^{20}$ Furthermore, she

16 Jane Herlihy and Stuart Turner, ‘The Psychology of Seeking Protection’ (2009) 21(2)

International Journal of Refugee Law, 180-181

17 Ibid.

18 Trevor Trueman, 'Reasons for Refusal: An Audit of 200 Refusals of Ethiopian Asylum Seekers in England' (2009) 23 Journal of Immigration Asylum and Nationality Law 281; Jessica Anderson and others, 'The Culture of Disbelief: An Ethnographic Approach to Understanding an UnderTheorised Concept in the UK Asylum System' (2014) Refugee Studies Centre 102 $<$ https://www.rsc.ox.ac.uk/files/publications/working-paper-series/wp102-culture-of-disbelief2014.pdf> accessed 4 December 2016.

19 United Kingdom Home Office, 'Asylum Policy Instruction: Assessing Credibility and Refugee Status' (2015) Version 9.0 p. 14

<https://www.gov.uk/government/uploads/system/uploads/attachment_data/file/397778/ASSESSI NG_CREDIBILITY_AND_REFUGEE_STATUS_V9_0.pdf> accessed 4 December 2016.

20 Juliet Cohen, 'Errors of Recall and Credibility: Can Omissions and Discrepancies in Successive Statements Reasonably Be Said to Undermine Credibility of Testimony?' (2001) 69 (25) MedicoLegal Journal. < $\underline{\text { https://www.lexisnexis.com/uk/legal/search/journalssubmitForm.do }>\text { accessed } 5}$ 
insightfully observes that for an asylum seeker to reproduce an exact account of a claim on every official occasion requires foreknowledge that consistency is a key prerequisite of credibility. Referring to the general treatment of witnesses before they appear in court, she asserts:

In Britain we give witnesses their statements to read before going into court, to ensure they are happy to swear to them on oath and to make sure they do not then depart from the 'established' story ... experience in the courts has shown it is almost impossible to maintain absolute consistency, especially if it is a long time since the events to be recalled. Yet this latitude is not given to asylum seekers who are repeatedly judged and found not credible on this very issue. This application of dual standards is iniquitous. ${ }^{21}$

Cohen's observation suggests that those who have an understanding of the importance attached to consistency in legal settings may be better equipped to reproduce an account that is exactly the same as that previously told, whereas those who lack such an understanding are at a disadvantage. The fact is that other witnesses are afforded the opportunity to be prepared for court hearings, but asylum seekers are not given this type of assistance. It can be inferred that a lack of preparedness of asylum seekers when appearing before decision makers may lead to unjust outcomes.

Furthermore, as noted earlier, language can also be a challenge for asylum seekers, who may be required to present their claims in a language other than their own. A number of studies have focused on linguistic aspects, including the role of translators and interpreters. ${ }^{22}$ However, language as a means of communication in the asylum process can serve two functions. The first is to present, generally through an interpreter, a basic response (irrespective of its relevance) to the question asked. The second function, and the main interest in this article, is the use of language ${ }^{23}$ to present a claim in a prescribed style,

March 2017

21 ibid.

22 Bogusia Temple, 'Crossed Wires: Interpreters, Translators, and Bilingual Workers in CrossLanguage Research’ (2002) 12 Qualitative Health Research 846

<http://qhr.sagepub.com/content/12/6/844.full.pdf> accessed 4 December 2016.

23 Pierre Bourdieu, Language and Symbolic Power (John B Thompson ed, Gino Raymond and Matthew Adamson trs, Polity 1991). 
irrespective of the applicant's command of the foreign language. As noted above, applicants must have a clear recollection of events, but they must also possess the communication skills to be able to describe them and present their claims in a detailed and coherent manner. This style of presentation is generally regarded as more credible and persuasive by authorities, and can therefore potentially affect the outcome of a claim. ${ }^{24}$

In an extensive discourse analysis of refugee status determination in Canada, Barsky shows that applicants tend to tell decision makers what they perceive they want to hear in order to be granted refugee status. ${ }^{25}$ Barsky argues that a refugee determination hearing is not merely an assessment of the applicant's credibility, but 'is more of a test of the applicant's ability to sort through his experience for appropriate selection', in order to fit his or her experiences into the legal definition of a refugee. ${ }^{26}$

Whether the experiences are 'true' or 'false' is hereby subordinated to the larger concern of whether this individual has adequately assessed the requirement of this hearing and is able to articulate appropriate content in an acceptable narrative form. In this sense, persons most familiar with Western forms of argumentative strategy and criteria for truth are favoured; long circular diatribes lacking detail may make reference to experience admissible according to the Convention but may do so in ways that are to our adjudicators incomprehensible and therefore unacceptable. ${ }^{27}$

Barsky sheds light on the skills and strategies that an applicant may need to articulate his or her asylum claim and the effect these may have on the outcome. His study highlights how the reception and outcome of a claim may depend significantly on the advantageous knowledge and skills possessed by an applicant. It also suggests that lacking such knowledge may be detrimental to the outcome.

24 UNHCR, 'Note on Burden and Standard of Proof in Refugee Claims' (16 December 1998) para 11 <http://www.refworld.org/docid/3ae6b3338.html> accessed 4 December 2016.

25 Robert F Barsky, Arguing and Justifying: Assessing the Convention Refugees' Choice of Moment, Motive and Host Country (Ashgate 2000); Barsky (n 1).

26 Barsky (n 1).

27 ibid. 
To be believed in a legal setting, speech styles are very influential. ${ }^{28}$ Therefore, the manner in which witnesses provide testimonies in such settings has long been of great interest to legal scholars. Conley, O’Barr, and Lind draw on empirical data to examine the effect of variations in the presentational styles of courtroom witnesses on legal decision makers. ${ }^{29}$ The authors analysed the speech styles of witnesses from a socio-linguistic perspective and identified four main linguistic patterns. First, some witnesses used 'powerful' and 'powerless' speech; secondly, testimony was delivered in 'narrative' and 'fragmented' styles; thirdly, 'hypercorrect' speech was used; and, fourthly, some testimony continued simultaneously with lawyers' interruptions and speech. ${ }^{30}$ The study showed that witnesses who speak in a naturally powerful and narrative manner, resisting interruptions, and continuing with their testimonies even while lawyers are questioning them, were viewed more favourably by the jury as credible witnesses. This finding suggests that using a 'definite style’ of presentation makes witnesses more credible. Conley, O’Barr, and Lind assert that this style of speaking can be traced back to the social and educational status of the speaker. ${ }^{31}$

\section{LEGAL FRAMEWORK}

Pursuant to article 35 of the Refugee Convention, ${ }^{32}$ UNHCR is tasked with promoting international instruments for the protection of refugees and supervizing their application. Subsequent European legal instruments, including the EU Procedures Directive, ${ }^{33}$ are to

28 B Erickson and others, 'Speech Style and Impression Formation in a Court Setting: The Effects of “Powerful” and “Powerless” Speech’ (1978) 14 Journal of Experimental Social Psychology 266.

29 John M Conley, William M O’Barr, and E Allan Lind, 'The Power of Language: Presentational Style in the Courtroom' (1979) Duke Law Journal 1375.

30 ibid 1379. 'Powerless' style is characterized by the frequent use of words and expression that convey a lack of forcefulness in speech.

31 ibid 1378.

32 Convention relating to the Status of Refugees (adopted 28 July 1951, entered into force 22 April 194) 189 UNTS 137 (Refugee Convention).

33 Council Directive 2005/85/EC of 1 December 2005 on minimum standards on procedures in Member States for granting and withdrawing refugee status [2 January 2006] OJ L326 13 December 2005, 13-34 <http://www.refworld.org/docid/4394203c4.html> accessed 4 December 
some degree based on elements of the European Convention on Human Rights, ${ }^{34}$ the Refugee Convention, and various UNHCR guidelines. The admissibility and content of testimony in court proceedings is governed by the rules of evidence, which provide few constraints on how testimonies are presented. ${ }^{35}$ The judiciary is presumed to be impartial to testimonial style and potentially influential factors, such as a witness's education, socio-economic background, culture, and language. ${ }^{36}$ Legal doctrine holds that these should have no bearing on the way testimonies are received. In the refugee status determination process, an asylum seeker's testimony is central since he or she is the sole 'witness' in the claim. As a result, in the absence of any corroborating evidence, the testimony presented in writing and orally at the asylum interview is the primary evidence in support of the claim. ${ }^{37}$ This is very significant, since the system for assessing claims favours a very particular style of testimony.

\subsection{UNHCR Handbook}

The 1951 Refugee Convention is the key legal document in defining who is a refugee, his or her rights, and the legal obligations of States. The UNHCR Handbook is intended for the guidance of government officials concerned with the determination of refugee status in the various contracting States. The concept of a 'well-founded fear of persecution' is the

2016. Council of the European Union, Directive 2013/32/EU of the European Parliament and of the Council of 26 June 2013 on common procedures for granting and withdrawing international protection (recast), 29 June 2013, OJ L. 180/60 -180/95; 29.6.2013, 2013/32/EU

<http://www.refworld.org/docid/51d29b224.html> [accessed 5 March 2017]

34 Convention for the Protection of Human Rights and Fundamental Freedoms (adopted 4 November 1950, entered into force 3 September 1953) ETS 5 (European Convention on Human Rights, 'ECHR')

35 Conley, O’Barr, and Lind (n 29) 1375-76.

36 AL Goodhart, Essays in Jurisprudence and the Common Law (CUP 1931) 15-16; see also JAG Griffith, The Politics of the Judiciary (Manchester University Press 1977). Judicial Skills and Abilities Framework (Courts and Tribunals Judiciary 2014) refers to the fact that the judiciary ought to have 'an awareness of the diversity of the communities which the courts and tribunals serve' p 5 <https://www.judiciary.gov.uk/publications/framework-of-judicial-abilities-andqualities/> accessed 4 December 2016.

37 UNHCR Handbook (n 5) para 196. 
principal criterion for establishing refugee status. It reflects the transformation of a system based on recognizing categories of people as refugees, as in the League of Nations Arrangement of $1926,{ }^{38}$ to a more individualistic approach, based on individual circumstances and testimony. ${ }^{39}$ As a result, the determination of refugee status, given that a fear of persecution is subjective, 'will primarily require an evaluation of the applicant's statements rather than a judgement on the situation prevailing in his country of origin'. ${ }^{40}$ This approach places more emphasis on the applicant's own interpretation of his or her situation and the communication of this to the official determining refugee status.

Hathaway and Foster provide a detailed analysis in relation to the concept of a wellfounded fear of persecution. They note that a well-founded fear involves two requirements: a subjective perception of risk and an objectively verifiable risk, based on conditions in the State of origin, since the fear must have a rational basis and be reasonable. ${ }^{41}$ As for persecution, it is constructed by serious harm and the failure of the State of origin to protect the individual. ${ }^{42}$ However, they argue that the concept of 'well-founded fear' is inherently objective. This is because in the absence of the objective element refugee status is denied, whereas the subjective element does not carry equal weight, since its presence does not guarantee refugee status. $^{43}$

Hathaway and Foster draw attention to the difficulty in assessing a subjective perception of fear and argue that, as a result of this difficulty, lack of credibility has been equated with an absence of subjective fear. ${ }^{44}$ Through case law analysis, they show that 'the

38 Arrangement of 12 May 1926 relating to the Issue of Identity Certificates to Russian and Armenian Refugees, 89 LNTS 2004, 47. An array of treaties before the 1951 Refugee Convention is testimony to this transformation. For a list of these provisions, see also Refugee Convention (n 32) art 1(1).

39 James C Hathaway, 'The Evolution of Refugee Status in International Law: 1920-1950’ (1984) 33 International and Comparative Law Quarterly 370. p. 370

$40 \quad$ UNHCR Handbook (n 5) para 37.

41 James C Hathaway and Michelle Foster, The Law of Refugee Status (2nd edn, CUP 2014) 91-92.

42 ibid 185.

43 ibid 92.

44 ibid 100. 
premise that applicants found not to be credible necessarily lack subjective fear is fundamentally illogical, as it erroneously assumes that fearful applicants do not lie or exaggerate in the course of relating their story'. ${ }^{45}$

It must be noted that the complexity of human experiences and the ability to articulate such experiences are at the core of the challenges faced by applicants for refugee status. The UNHCR Handbook highlights that the persecution may stem from any one cause or a combination of reasons related to race, religion, nationality, membership of a particular social group, or political opinion. Significantly, it also points out that: 'Often the applicant himself may not be aware of the reasons for the persecution feared. It is not, however, his duty to analyse his case to such an extent as to identify the reasons in detail'. ${ }^{46}$ Hence, it can be inferred that the applicant is not expected to evaluate the reasons or circumstances relating to his or her own claim to such a degree that he or she can identify and articulate these facts in detail.

Given that an applicant is not required to provide detailed reasons for his or her persecution, it is important to identify where this responsibility then lies. According to the Handbook, '[i]t is for the examiner, when investigating the facts of the case, to ascertain the reason or reasons for the persecution feared and to decide whether the definition in the 1951 Refugee Convention is met with in this respect'. ${ }^{47}$ In view of the reality and messiness of the lived experience of persecution, the reasons set out in the Handbook (as mentioned above) often overlap and intersect; for example, the Handbook refers to 'a political opponent who belongs to a religious or national group, or both'. ${ }^{48}$ It is reasonable, therefore, to leave the duty of evaluation of such issues to a decision maker, since an applicant belonging to a persecuted religious group as well as a persecuted national group may not be able to analyse his or her circumstances in order to clearly identify whether the reason(s) for his or her fear of persecution stem from religious or national affiliations.

On examining paragraphs 66, 67, 195, and 196 of the Handbook, it can be noted that,

\footnotetext{
45 ibid 101.

46 UNHCR Handbook (n 5) para 66.

47 ibid para 67.

48 ibid.
} 
although paragraphs 66 and 67 appear under the heading of 'General analysis' ${ }^{49}$ for the five Convention grounds, their application has, in fact, a narrower focus, in that they deal with the reasons for persecution only. Paragraphs 195 and 196, on the other hand, have a much broader focus, ${ }^{50}$ dealing with all the relevant facts of the claim. These facts have a broader remit than the reasons for persecution, although the latter may arguably represent the most fundamental aspect of the former.

According to the Handbook:

[W] hile the burden of proof in principle rests on the applicant, the duty to ascertain and evaluate all the relevant facts is shared between the applicant and the examiner. Indeed, in some cases, it may be for the examiner to use all the means at his disposal to produce the necessary evidence in support of the application. ${ }^{51}$

Furthermore, paragraphs 195 and 196 state that although the first step in supplying the facts rests with the applicant, the subsequent steps, first to ascertain and then to evaluate all the relevant facts, should be shared. Since the term 'shared duty' is not qualified by any adverb or quantified, it may be interpreted as meaning that responsibility is apportioned equally to each party.

This analysis of the Handbook’s guidelines reveals that paragraphs 66 and 196 contain contradictory instructions, not previously identified in the literature. Paragraph 66 assigns to the examiner full responsibility 'to identify the reasons in detail', whereas paragraph 196 ascribes a shared duty, which may be interpreted as meaning that the responsibility is shared. Given this, it is reasonable to suggest that the examiner should bear greater overall responsibility than the applicant.

First, the applicant does not have a duty to analyse his or her case to the extent of

49 ibid Part One, pp 15-16: Criteria for the Determination of Refugee Status, Chapter Two: Inclusion Clauses, Section B: Interpretation of Terms, (3): 'for reasons of race, religion, nationality, membership of a particular social group or political opinion’, (a) General analysis.

50 ibid Part Two: Procedures for the Determination of Refugee Status, Section B: Establishing the Facts, (1) Principles and Methods. p 38

51 ibid para 196. 
identifying the reasons for persecution in detail. In other words, it should not jeopardize the claim if he or she does not know the relevant facts or the reasons that underpin the alleged persecution, since it is the duty of the examiner to uncover these details. Secondly, the duty to ascertain and evaluate all the relevant facts is shared. The Handbook places the main responsibility for providing the material facts of an asylum claim on the applicant. However, as shown, identification of the reason(s) for persecution in detail is not the applicant's duty. This sits uncomfortably with a shared duty of identification and evaluation of all the other relevant facts, since an analysis of reasons is needed in order to establish these facts. If an applicant for refugee status is unaware of concepts such as persecution, discrimination, and human rights violations, or, indeed, of the Convention's grounds for persecution, then he or she would arguably be unable to sift through his or her life experiences and locate, identify, retrieve, and communicate the facts relevant to those events. Hence, the applicant is to a large extent at the mercy of the decision maker's skill in eliciting these facts.

Goodwin-Gill and McAdam, referring to the inherently subjective and futuristic nature of a serious risk of harm, point to the crucial role of the factual evidence given by the applicant, and argue that 'the credibility of the applicant and the weight of the evidence are thus of critical importance'. ${ }^{52}$ This argument underlines the significance of the testimonies offered by asylum seekers. The applicant may face serious difficulties in providing evidence to substantiate his or her claim. This difficulty is acknowledged by the law in that the burden of proof is not as high as the balance of probabilities. ${ }^{53}$ It is this lower burden of proof and the role of the examiner that should be considered when evaluating the testimonies.

\subsection{UKVI Asylum Policy Instruction}

In the UK, the initial decision regarding an asylum claim is made by a government official on behalf of the Home Secretary. The UK Visas and Immigration department (UKVI) is part of the Home Office and provides Asylum Policy Instruction (API) for the examiners, also called caseworkers, who initially decide asylum claims. The API sets out the processes and procedures to be followed when claims are considered. These instructions are an

52 Guy S Goodwin-Gill and Jane McAdam, The Refugee in International Law (3rd edn, OUP 2007) 542.

53 ibid. 
amalgamation of guidance and rules provided in the UNHCR Handbook, European law, ${ }^{54}$ UK legislation, ${ }^{55}$ and the UK Immigration Rules. ${ }^{56}$ The Home Office, UKVI, and the API solely govern the initial decision-making process, while the Immigration and Asylum Chamber, First-Tier Tribunal, has its own Practice Directions ${ }^{57}$ and Procedural Rules, ${ }^{58}$ which govern the appeals procedure for asylum seekers whose claims have been refused by the Home Office. However, asylum seekers subject to the Home Office's initial decisionmaking process do not enjoy the same rigorous procedural fairness and scrutiny that is applied in tribunals, and the criminal and civil courts in the UK.

The UKVI frequently cites the UNHCR Handbook as authoritative guidance. ${ }^{59}$ Expanding upon UNHCR guidance, UKVI guidelines state that asylum seekers should present a detailed, coherent, and consistent account of their claim if the events they are recalling have really happened to them. ${ }^{60}$ Referring to paragraph 195 of the UNHCR Handbook, the API states that: 'Caseworkers must first identify what is actually relevant to the claim'. ${ }^{61}$ Contrary to paragraph 66 of the Handbook, ${ }^{62}$ the API had emphasized the necessity for a detailed account of the circumstances and reasons for the claim. ${ }^{63}$ In fact, the

54 Council Directive 2005/85/EC (n 33). Directive 2013/32/EU

55 Asylum and Immigration (Treatment of Claimants, etc) Act 2004, s 8.

56 Immigration Rules para 339.

57 Practice Direction of the Immigration and Asylum Chambers of the First-Tier and Upper Tribunal on or after 13 November 2014 <https://www.judiciary.gov.uk/publications/practice-direction-ofthe-immigration-and-asylum-chambers-of-the-first-tier-and-upper-tribunal-on-or-after-13november-2014/> accessed 4 December 2016.

58 Tribunals and Inquiries: The Tribunal Procedure (First-Tier Tribunal) (Immigration and Asylum Chamber) Rules 2014, SI 2014 No 2604 (L 31).

59 API (n 19).

60 ibid para 5.6.2.

61 API (n19) p 11.

62 UNHCR Handbook (n 5) para 66: 'It is not, however, his [the applicant's] duty to analyze his case to such an extent as to identify the reasons in detail.'

63 UK Home Office, ‘Considering Asylum Claims and Assessing Credibility’ (2012) p.14 
2012 version of the instruction, ${ }^{64}$ in operation at the time of data analysis for this article, specifies a particular mode of testimony:

The level of detail with which an applicant sets out a claim about the past and present is a factor which may influence a decision maker when assessing internal credibility. It is reasonable to expect, subject to mitigating circumstances, that an applicant relating an experience that occurred to them will be more expressive and include sensory details such as what they saw, heard, felt or thought about an event, than someone who has not had this experience. Notwithstanding any mitigating circumstances, it is a reasonable expectation for an applicant to recount an event to the level of detail that can be reasonably expected of an individual who has experienced the claimed event. ${ }^{65}$

The 2015 version of the API does not go as far as the earlier document in specifying the type of detail expected in an applicant's account but, nevertheless, states that 'sufficiency of details and specificity' should be provided. ${ }^{66}$ However, the author's analysis of the standard template used for screening and substantive interviews ${ }^{67}$ shows that it may not facilitate the elicitation of a sufficiently detailed and coherent account, as required by the UNHCR Handbook. ${ }^{68}$

It is clear that the UKVI favours and perceives as more credible a very particular testimonial style. There appears to be an assumption that applicants who have experienced an event are able, or ought to be able, to recollect it in a manner which satisfies the criteria. As noted earlier, according to paragraph 66 of the UNHCR Handbook, an applicant is not expected to evaluate his or her own claim, or, more precisely, the reasons for persecution, to such a degree that he or she can identify these reasons and articulate them in detail to the examiner. In contrast, the UKVI expects a very detailed account. This reaffirms the earlier focus on the two contradictory instructions in paragraphs 66 and 196 in the UNHCR

<http://www.refworld.org/docid/5449ffa84.html> accessed 4 December 2016.

65 ibid para 4.3.1 and p.13.

66 API (n 19).

67 Template ASL.3211a Screening Interview Stage 1, used by the Home Office.

68 UNHCR Handbook (n 5) para 240. 
Handbook which, coupled with the approach taken by the UKVI, could lead to procedural unfairness.

Procedural unfairness is manifested in a threefold challenge to applicants. First, in light of the above analysis of paragraph 66 of the UNHCR Handbook, often the applicant may not be aware of the reasons for the persecution feared, and it is not his or her duty to analyse the case to such an extent as to identify them in detail. Secondly, the identification of the reasons in detail is, in theory, weighted towards the examiner. These inferences, coupled with paragraph 66, confirm that the applicant's ignorance of the reasons means that he or she cannot possibly provide all the relevant material facts, including the reasons for persecution. Thirdly, the UKVI expects only relevant and material facts to be presented in a detailed, coherent, and consistent account, which, in view of the two challenges mentioned above, is unreasonable.

It is clear that asylum seekers face major challenges when presenting a protection claim. First, there is the expectation of a detailed account. This presents difficulties because, in addition to psychological and inter-cultural challenges, the skills involved in presenting an asylum claim in the prescribed manner have been shown to be highly significant. Barsky argues that the assessment of credibility is a test of an asylum seeker's ability to appropriately select the relevant experiences and to provide the decision maker with what he or she expects to hear, while Conley, O’Barr, and Lind focus on the presentational style of witnesses in courtrooms. A second major challenge is the expectation - set out in the API - that applicants should be able to identify the reasons for their persecution to such a degree that they can articulate them in detail to the official. However, paragraph 196 of the UNHCR Handbook states that responsibility for this should be shared, and paragraph 66 removes such a duty. This article seeks to explore, on the basis of empirical evidence, differences in presentational style that may cause difficulties for asylum seekers in presenting their claims to UK authorities.

\section{METHODOLOGY}

The data presented in this article was collected from two Iranian participants, interviewed at Keele University in the UK. The participants were recruited through a law firm and two Iranian associations, and were previously unknown to the author, also Iranian, who conducted the interviews in Farsi and translated the recordings into English. 
The same interview procedure, detailed below, was used with both men; the location, length of interview, and interviewer were also the same. Before the interviews, the participants were given a letter of invitation and an information sheet, setting out the background and aims of the research. They also completed consent forms and participated freely, without any financial compensation.

The interviews used the Biographical Narrative Interpretive Method, which is a qualitative method of data collection and analysis, falling under a 'narrative methods' rubric. That is, it is based upon eliciting and interpreting narrative. ${ }^{69}$ This article draws on empirical data gathered using a type of biographical narrative method pioneered by Hollway and Jefferson, called Free Association Narrative Interview (FANI). ${ }^{70}$ Hollway and Jefferson emphasize the potential of this method to minimize the role and influence of the researcher and to reduce practised and clichéd responses. The method consists of two in-depth interviews. The first interview aims to establish an understanding of the life story of the participant and bring to light any contradictions, inconsistencies, avoidances, and changes of emotional tone. ${ }^{71}$ The second interview acts as a check and gap-filling process that enables researchers to seek further exploration of any identified contradictions, defensiveness, or avoidances, and to further test their intuitions. ${ }^{72}$

The FANI method was used to collect the data for a larger study, of which this article forms a part. Data collection and data analysis for the larger study were undertaken solely by the author. The study was subject to ethical scrutiny and approval in line with Keele University procedures. This particular method of data collection was chosen to avoid fragmentation of the data and to give participants the greatest level of control over the process of data generation. Informed by the FANI method, data was collected through in-

69 Prue Chamberlayne, Joanna Bornat, and Tom Wengraf (eds), The Turn to Biographical Methods in Social Science: Comparative Issues and Examples (Routledge 2000); Tom Wengraf, Qualitative Research Interviewing: Biographic Narrative and Semi-Structured Methods (Sage 2001); Catherine Kohler Riessman, Narrative Methods for the Human Sciences (Sage 2008).

70 Wendy Hollway and Tony Jefferson, Doing Qualitative Research Differently: Free Association, Narrative and the Interview Method (Sage 2000).

71 ibid 43.

72 ibid. 
depth interviews, each lasting approximately two hours, ${ }^{73}$ which elicited autobiographical accounts from a sample of 10 participants in total. This method of data collection seeks to avoid direct questions and attempts to go beyond the answers generated by questions such as: 'Why did you seek asylum in the UK?' Instead, the question put to participants was: 'Can you tell me the story of your life?' Although this appears to be a very broad question, the intention was that participants would have a clear idea about the purpose of the study from the information relayed to them before the interview. Asking a broad question at the start of the interview handed control of data generation to the interviewees, in essence giving them the liberty to choose to focus on their story of asylum or to go further afield and start from their earlier experiences. One of the two participants, Bahram, ${ }^{74}$ gave a very detailed, chronological, and coherent account and refused to take part in a second interview. The other participant, Pouya, agreed to the second interview. For the purpose of this article, data from each man’s first interview has been compared.

It is recognized that the interview data presented in this article does not accurately represent the information generated during the participants' substantive interviews with Home Office examiners. The data may, nevertheless, offer insights into the process and be regarded as indicative of the applicants' testimonial styles. It is also reasonable to suggest that the differing styles of presentation that emerged in this study may reflect styles typically used by other applicants during official asylum interviews. In addition, while Bahram consented to one interview only, he explicitly stated that this was a true recollection of the account he had given to the Home Office. Pouya's testimonial style was corroborated by a body of other legal evidence that he agreed to provide: a copy of his substantive interview with the Home Office; his refusal letter from the Home Office; his grounds of appeal challenging the Home Office refusal; and the tribunal's decision in dismissing his appeal. All these documents corroborated the particular presentational skills he demonstrated during the interview in this study, although they were not analysed in detail for this article.

The similarities between these two participants regarding their personal characteristics and asylum claims, together with their different narrative styles and claim outcomes, called for a thematic and comparative approach to data analysis. Comparison of the two sets of presentational skills provided valuable insights into the way their testimonies may have been

\footnotetext{
73 Hollway and Jefferson (n 70).

74 To maintain anonymity, one man was given the pseudonym 'Bahram', and the other 'Pouya'.
} 
presented to the examiners in the course of their substantive asylum interviews.

Section 5.6 of the $\mathrm{API}^{75}$ provides guidance for caseworkers assessing asylum seekers' credibility, highlighting the importance of certain internal and external credibility indicators. Internal credibility is associated with the coherence and consistency of an applicant's account, while external credibility corresponds to consistency in relation to known facts about the country of origin. According to the API, internal credibility comprises two main components. First, an asylum seeker's account must have sufficient detail and specificity. In addition, 'the level and nature of information provided by the applicant should demonstrate a reasonable depth of personal experience and knowledge, allowing for any underlying reasons'. ${ }^{76}$ Secondly, the account should be consistent and coherent (to a reasonable degree), ${ }^{77}$ and 'there should be no significant or inadequately explained gaps or contradictions' ${ }^{78}$ In this regard, the API expects caseworkers to put to the applicant any identified contradictions in their past and present statements.

API internal credibility indicators include: level of detail, sensory detail, coherence, in/consistency, gaps, and contradictions. These indicators were further refined when considering the comparative nature of the data from the two men's first interviews, and it was decided that, for the purpose of highlighting differences in presentational skills, ${ }^{79}$ the

75 API (n 19) section 5.6 p $14-15$.

76 ibid para 5.6.1 . Underlying factors may include: age, gender, variations in the capacity of human memory, physical and mental health, emotional trauma, lack of education, social status and cultural traditions, feelings of shame, and painful memories, particularly those of a sexual nature, p.14However, it is debatable whether these underlying factors are identified and explored in practice.

77 ibid para 5.6.2, p.15 .

78 ibid para 5.6.2, p.15

79 Conley, O’Barr, and Lind (n 29) refer to the testimonial style of witnesses, and define presentational style as including both verbal and non-verbal behaviours. They seem to refer to testimonial styles and presentational styles interchangeably. However, in this article, 'presentational skill' refers to the ability (or inability) of an applicant to present a claim in the prescribed manner; it is confined to verbal and written statements, and excludes non-verbal behaviour. 
following correspondence of UKVI indicators to applied indicators was justified.

Two API indicators - 'Level of (informational) detail' and 'Level of sensory details' - were retained in the analysis, and an additional category - 'Chronological versus nonchronological information' - was created. While the new category related to the 'Level of detail', it focused on the organization of information in the two accounts. The API indicator 'In/consistency, inadequately explained gaps and potential contradictions' - was not used directly, but a related indicator - 'Anticipating the line of questioning' - was included. Table 1 below displays the correspondence between UKVI credibility indicators and indicators that were applied to the data in this study.

Table 1. Comparison of credibility indicators

\begin{tabular}{|l|l|}
\hline Credibility indicators used by UKVI & $\begin{array}{l}\text { Credibility indicators applied in this } \\
\text { study }\end{array}$ \\
\hline Coherence, consistency, and gaps & $\begin{array}{l}\text { 1. Chronological versus non-chronological } \\
\text { organization of information }\end{array}$ \\
\hline Level of detail & 2. Level of informational detail \\
\hline $\begin{array}{l}\text { Level of sensory detail } \\
\text { In/consistency, inadequately explained gaps, } \\
\text { and potential contradictions }\end{array}$ & $\begin{array}{l}\text { 3. Level of sensory detail } \\
\end{array}$ \\
\hline
\end{tabular}

\section{DATA ANALYSIS}

This study focused on two men who were friends and came from the same hometown in southern Iran. Apart from marital status (one man was married, the other unmarried), the men shared a large number of characteristics. Both were 34-35 years old, and each had had six to seven years of schooling. They came from similar socio-economic backgrounds and had similar income levels. In addition, the men held the same jobs in Iran (both were construction workers on the same site, and later, taxi drivers). They also had the same friends and were related. They shared ethnicity, religion (Islam), sexual orientation, and political opinions. Moreover, neither man had previously travelled outside Iran, and both had been in hiding for 
over a year before leaving Iran around the same time. Both men feared persecution on the same Convention grounds.

The two men were, therefore, very similar in terms of measurable factors/variables that might influence the outcome of their asylum claims. Both had gone into hiding after experiencing problems with the authorities in the aftermath of the disputed 2009 presidential election in Iran. ${ }^{80}$ They left Iran at around the same time and crossed the border to Turkey. From there, they boarded a number of different lorries, and after negotiation with drivers, eventually arrived, only six days apart, in the same city in the UK. In addition to having taken very similar travel routes, the men claimed asylum upon arrival on identical grounds. The basis of both asylum claims was their fear of persecution following active participation in the June 2009 presidential election campaign and their work as drivers and distributors of campaign materials. Nevertheless, the data from their interviews shows that, in contrast to the above similarities, there were significant differences in the way the men presented their claims.

\subsection{Differences in narrative style and content}

The men had noticeably different narrative styles in the course of their interviews, each of which commenced with the same question: 'Can you tell me the story of your life?' After some enquiry as to when and where should he start, and reassurance that he could 'start as far back as [he wanted] and take as long as [he liked]', Bahram assertively said, 'I would like to start from the election ${ }^{81}$ and, without hesitation, began with this pivotal event in the circumstances leading to his asylum claim. Bahram’s job as a taxi driver and the contributions he made to distributing materials and posters for street demonstrations using his car comprised the core of his claim. He therefore began purposefully with the important event of the election, also providing some concise background and context: 'It was in the atmosphere of pre-election mood. I was working as a driver for a health centre'. Thereafter, he provided a very linear, chronological, and purposeful account of his involvement with the supporters of presidential candidate, Mir-Hossein Mousavi. His account was supported by dates, durations, and times, with events following logically and chronologically.

\footnotetext{
80 Ali M Ansari, Crisis of Authority: Iran’s 2009 Presidential Election (Chatham House 2010).

81 ibid. 'The election' refers to Iran's 10th presidential election in 2009, which was followed by mass street demonstrations across Iran in protest at alleged electoral fraud.
} 
Pouya, on the other hand, in the same interview setting and asked the same question, began with: 'Our house still has British electric[al] sockets; our doors and windows, gable roof and our ceiling belong to 60 years ago'. Presenting seemingly irrelevant information, his account began with the big picture, the start of the whole story of Iran and Britain's relations. He provided a remarkably different account of the events leading to his claim. His style of narration was circular and marred by gaps.

The men's contrasting narrative styles and content are evident in their responses to the initial interview prompt: 'Can you tell me the story of your life?' The first paragraph of each man's transcript illustrates the differences in narrative styles between the two. It also provides sufficient evidence to demonstrate the first impression each man conveys, which may have consequences. Table 2 displays the unedited first paragraphs from the two men's responses to the first question.

Table 2. Responses to the initial interview question: 'Can you tell me the story of your life?'

\begin{tabular}{|l|l|}
\hline Bahram & Pouya \\
\hline 'I would like to start from the election. It & 'Our house still has British electric \\
was in the atmosphere of pre-election & sockets; our doors and windows, gable \\
mood. I was working as a driver for a & roof and our ceiling belong to 60 years \\
health centre. I had a car. My car was a & ago. They were built 60 years ago and \\
Pride model. I transported nurses and & even now there is not one single drop of \\
those on various shifts and I also had jobs & leak from them. When I thought of leaving \\
for city A.* I would bring doctors and & Iran, I didn't particularly want to come to \\
would take them back between city B and & England; I just wanted to leave. It was my \\
city A; it's about 180 kilometres. Then, & first time crossing Iran's borders. This is \\
when my official and structured work time & my first time in Europe. I was very \\
ended, I would continue to work at the & unhappy with the general situation in \\
terminals as a self-employed driver. Here I & Iran; my contractor would receive \\
dealt with university students, & 700,000 tomans from the government as \\
transporting them to city C. From city B, I & my gross wages. By the time it reached my \\
went to city C; I was in this route between & hand, it was down to 250,000 as my net \\
\hline
\end{tabular}




\begin{tabular}{|c|c|}
\hline $\begin{array}{l}\text { the two universities in city B and city C. It } \\
\text { was three months before the election; the } \\
\text { actual presidential election of } 2009 \text { was } \\
\text { approaching. The students kept talking } \\
\text { about it in my car in our way to the } \\
\text { destinations. I was popular as I was lively } \\
\text { and talkative.' }\end{array}$ & $\begin{array}{l}\text { wages. My parents were government's } \\
\text { employee and they were transferred to } \\
\text { city B. We were given a 3-bedroom } \\
\text { bungalow to live in; it was designed by } \\
\text { English; the width of the walls between } \\
\text { rooms was } 60 \text { centimetres. There are oil } \\
\text { wells that are still sealed and remain as } \\
\text { the British left them.' }\end{array}$ \\
\hline
\end{tabular}

* The names of cities have been removed to maintain confidentiality.

Analysis of this unedited data revealed significant dissimilarities in the openings of the two accounts in response to the same question, within an identical interview setting. It also illustrated the importance of first impressions and their role in interviews, since the men used this opportunity in different ways. Bahram's account is methodical, chronological, and detailed. He begins with the election, suggesting that he sees this as central to his asylum claim. Pouya's account, on the other hand, is non-chronological and unstructured. It offers some details but these are not strictly relevant to his claim. Pouya talks about the historical links between Iran and Britain, something that has influenced his perception of his worthiness to be granted refugee status, but his reference to this is too broad to purposefully contribute to his asylum claim. These differences in approach to narration demonstrate a consistent pattern that continued throughout the two men's interviews.

From the perspective of the API, it can be argued that Bahram is relating an experience that actually happened to him, since his testimonial style matches that expected from credible applicants. This argument would also suggest that, since Pouya deviates from this particular testimonial style, he has not experienced the events he describes as leading to his asylum claim. In other words, Bahram appears to be a credible witness, whereas Pouya does not. This interpretation, however, may not be valid because both men essentially recall the same type of events, even though their testimonial styles differ. It has been established that producing 'highly specific details does not guarantee that a memory is accurate or even that it actually occurred' ${ }^{82}$ Further analysis of the data reveals the extent to which Bahram

82 Martin A Conway and Emily A Holmes, Guidelines on Memory and the Law: Recommendations from the Scientific Study of Human Memory (The British Psychological Society 2008) p.2. See 
and Pouya's testimonies match or depart from the criteria for credibility prescribed in the UNHCR Handbook guidelines and the API.

In the following sections, data relating to four key credibility indicators is presented in tabular form, with Bahram and Pouya's narrations displayed side by side to make comparison easier. The order of the data displayed in these four tables is faithful to the chronology in which the men recollected their stories during the course of their interviews.

\subsubsection{Chronological versus non-chronological organization of information}

In Table 3 below, the numbers 1-15 represent the order in which Bahram and Pouya recounted events. Some events were experienced by both men but not related in the same order. For example, recruitment as a driver for the presidential election campaign appears as the second point in Bahram's account, whereas it is the eighth point in Pouya's account. Bolded text allows readers to cross-reference the same event in the two accounts.

Table 3. Chronological versus non-chronological organization of information as an indicator of credibility

\begin{tabular}{|l|l|}
\hline Bahram (chronological) & Pouya (non-chronological) \\
\hline $\begin{array}{l}\text { 1. Events a few months before the election } \\
\text { 1. Positive collective memories of British } \\
\text { influence in southern Iran (decades ago, } \\
\text { before his birth) }\end{array}$ \\
$\begin{array}{l}\text { 2. Events leading to his recruitment as a } \\
\text { campaign for the presidential election }\end{array}$ & 2. His first time crossing Iran's borders \\
\hline $\begin{array}{l}\text { 3. Events during his contribution to the } \\
\text { campaign of Mir-Hossein Mousavi }\end{array}$ & $\begin{array}{l}\text { 3. Unhappiness with the general situation } \\
\text { in Iran (unfair payment for work) }\end{array}$ \\
\hline
\end{tabular}

also James P Eyster, 'Searching for the Key in the Wrong Place: Why “Common Sense” Credibility Rules Consistently Harm Refugees’ (2012) 30 Boston University International Law Journal, p 39. 


\begin{tabular}{|c|c|}
\hline [see Pouya, 9] & \\
\hline $\begin{array}{l}\text { 4. Events during the street } \\
\text { demonstrations } \\
\text { [see Pouya, 10] }\end{array}$ & $\begin{array}{l}\text { 4. Parents' relocation to city B and } \\
\text { description of the new house }\end{array}$ \\
\hline $\begin{array}{l}\text { 5. Events leading to his fear of persecution } \\
\text { [see Pouya, 11] }\end{array}$ & $\begin{array}{l}\text { 5. Disappointment with Afghan } \\
\text { interpreter (in UK asylum system) }\end{array}$ \\
\hline $\begin{array}{l}\text { 6. Escape from his hometown } \\
\text { [see Pouya, 11] }\end{array}$ & $\begin{array}{l}\text { 6. Severe toothache during his substantive } \\
\text { interview }\end{array}$ \\
\hline $\begin{array}{l}\text { 7. Period of hiding in another location } \\
\text { [see Pouya, 7] }\end{array}$ & $\begin{array}{l}\text { 7. Period of hiding in another location } \\
\text { [see Bahram, 7] }\end{array}$ \\
\hline 8. Decision to leave Iran & $\begin{array}{l}\text { 8. Recruitment as a driver for the } \\
\text { presidential election campaign } \\
\text { [see Bahram, 2] }\end{array}$ \\
\hline $\begin{array}{l}\text { 9. Travel to Turkey and boarding lorries } \\
\text { (by negotiation, not clandestinely) }\end{array}$ & $\begin{array}{l}\text { 9. His contribution to the campaign of Mir- } \\
\text { Hossein Mousavi } \\
\text { [see Bahram, 3] }\end{array}$ \\
\hline 10. Experiences on board four lorries & $\begin{array}{l}\text { 10. Reference to street demonstrations } \\
\text { [see Bahram, 4] }\end{array}$ \\
\hline $\begin{array}{l}\text { 11. Arrival in the UK and the experience of } \\
\text { being abandoned on a motorway }\end{array}$ & $\begin{array}{l}\text { 11. Reference to his fear and flight: 'I } \\
\text { escaped out of fear' } \\
\text { [see Bahram 5, 6] }\end{array}$ \\
\hline 12. Seeking asylum in Leeds & $\begin{array}{l}\text { 12. Experiences involving lawyers, the } \\
\text { appeal, and judge }\end{array}$ \\
\hline
\end{tabular}


13. Reaching West Croydon and giving a substantive interview

14. Treatment by the official/caseworker

15. Granting of refugee status after one week
13. General insecurity in Iran

14. The role of Sepah and Basij (Iran's military and paramilitary militia)

15. Iran failing its youth

As Table 3 shows, Bahram provides a chronological account which is purposeful and to the point, almost mechanical and, possibly, well prepared. In particular, he recounts the events leading to his flight from Iran in chronological order. Pouya, however, sets a scene that, on the face of it, is irrelevant to his claim, and his narrative is not logically structured. Unlike Bahram, he does not explain events chronologically, providing information about the events that led to his flight only after focusing on more random information. He provides simple, very short explanations, and delays presenting the important chronological and constituent parts of his asylum claim. His account may be viewed as random, with only a few points of apparent relevance, whereas Bahram moves through all the events chronologically. Bahram's account may also be considered as showing linear progression, with a step-by-step approach, moving from general to more specific information. Bahram appears to adhere to a more Western style of narration, while Pouya's style may be more aligned with a circuitous, typically Eastern, style of expression. ${ }^{83}$

At point 7 in the sequence of events, both men refer to a period of hiding. Bahram describes the events leading up to this in points 1-6, while Pouya appears to describe the events in reverse order, presenting the events that led to his hiding (points 8-11) only after mentioning the period of hiding (point 7), and his account lacks coherence. In addition, the

83 Ehsan Alijanian and Hossein Vahid Dastjerdi, 'The Use of Indirectness Devices in Persian and English Argumentative Written Discourse: A Cross-Cultural Perspective’ (2012) 4 International Journal of Linguistics 60; Robert B Kaplan, 'Cultural Thought Patterns in Inter-Cultural Education' (1966) 16 Language Learning 1; Aiju Yu, 'Analysis of the Problems of the Chinese College Students’ EFL Classroom Writings’ (2012) 5 International Education Studies 199; Junhong Ren and Na Wang, 'A Survey on College English Writing in China: A Cultural Perspective’ (2014) 8 English Language Teaching 21. 
information he provides before point 7 does not seem as relevant in terms of key indicators and material facts. Bahram is adept and systematic in his account, whereas Pouya supplies seemingly random information before he reaches the same key event (point 7). Bahram's delivery is in a narrative form, whereas Pouya's is fragmented and, according to Conley, O’Barr, and Lind, in a legal setting these styles are indicators of credible and disbelieved witnesses respectively. ${ }^{84}$

\subsubsection{Level of informational detail}

Table 4 below examines the different narrative styles adopted by Bahram and Pouya, particularly in relation to the amount of detail that each man includes. At times, they report identical events with different degrees of detail. The numbers in this table refer to the order in which each point was expressed in the interviews and for ease of reference in terms of analysis. For instance, point 3 in Bahram's extract can be compared to point 5 from Pouya's. Bolded text allows like-for-like comparison of the two accounts in relation to cells 3 and 5 , and also cells 9 and 9 .

Table 4. Level of informational detail (given names, family names, dates, distances, locations) as an indicator of credibility

\begin{tabular}{|c|c|}
\hline Bahram & Pouya \\
\hline 1. Atmosphere: 'pre-election mood' & $\begin{array}{l}\text { 1. Family bungalow 'built } 60 \text { years ago' by } \\
\text { the British }\end{array}$ \\
\hline 2. Car model: 'Pride' & $\begin{array}{l}\text { 2. 'The width of the walls between rooms } \\
\text { was } 60 \text { centimetres.' }\end{array}$ \\
\hline $\begin{array}{l}\text { 3. Distance between city B and city A: 'it's } \\
\text { about } 180 \text { kilometres' } \\
\text { [see Pouya, 5] }\end{array}$ & $\begin{array}{l}\text { 3. Wage details: } 700,000 \text { and } 250,000 \\
\text { tomans }\end{array}$ \\
\hline $\begin{array}{l}\text { 4. 'It was three months before the } \\
\text { election; the actual presidential election }\end{array}$ & 4. Names cities $A$ and $B$ \\
\hline
\end{tabular}

84 Conley, O’Barr, and Lind (n 29). pp, 1386 - 1387 


\begin{tabular}{|l|l|}
\hline of 2009 was approaching.' & \\
\hline $\begin{array}{l}\text { 5. 'The day of election was 12 June 2009; } \\
\text { on 13 June the results were announced. I } \\
\text { then was in two demonstrations, one on } \\
\text { 17 June and the other one on 20 June, } \\
\text { both in city A.' }\end{array}$ & [see Bahram, 3] \\
\hline $\begin{array}{l}\text { 6. Precise position: 'My friend was right } \\
\text { next to me on my right-hand side, called } \\
\text { Saeed. I saw him fall down. He was } \\
\text { married with one child; he was one of my } \\
\text { relatives.' }\end{array}$ & 6. 'Mr H offered me the job.' \\
\hline $\begin{array}{l}\text { 7. Frequent use of given names and } \\
\text { family names }\end{array}$ & $\begin{array}{l}\text { [see Pouya, 9] } \\
\text { [see Bahram, 9] }\end{array}$ \\
\hline $\begin{array}{l}\text { 8. Names cities, boroughs, towns, } \\
\text { villages, streets, avenues, alleys, and } \\
\text { residential estates }\end{array}$ & $\begin{array}{l}\text { 8. Sepah and Basij: general atmosphere of } \\
\text { menace }\end{array}$ \\
\hline $\begin{array}{l}\text { 9. Refrigerated truck carrying apples } \\
\text { a. Refrigerated truck }\end{array}$ \\
\hline
\end{tabular}

Bahram offers a detailed and coherent account, providing information about the precise position of individuals around him, their full names, in addition to other memorable information. By contrast, Pouya's account is limited to the bare minimum of information. Bahram's detailed narrative is supported by people's names (given names and family names), the names of cities, towns, boroughs, streets, alleys, junctions, and stores. He also provides dates, from exact dates to durations, such as 'one day', 'one night', 'after few more days', 'for a week', 'I was in a house for 17 months'. Pouya seems less able to describe events and experiences vividly.

\subsubsection{Level of sensory detail}

Table 5 below shows data relevant to the sensory indicator. Numbering in this table is purely 
to facilitate analysis. Putting the two men's recollections of the same event side by side, at point 3, allows direct comparison of their different presentational styles with regard to sensory detail.

Table 5. Level of sensory detail (what the applicants saw, heard, smelt, felt, thought) as an indicator of credibility

\begin{tabular}{|c|c|}
\hline Bahram & Pouya \\
\hline $\begin{array}{l}\text { 1. 'My friend was right next to me on my } \\
\text { right-hand side, called Saeed. I saw him } \\
\text { fall down. He was married with one child; } \\
\text { he was one of my relatives. I went over to } \\
\text { him and held his head up and I could hear } \\
\text { him gasping for breath, his last breath. I } \\
\text { didn't leave him. Saeed was in my arms.' }\end{array}$ & $\begin{array}{l}\text { 1. During substantive interview with the } \\
\text { examiner: 'Nasty toothache'. }\end{array}$ \\
\hline $\begin{array}{l}\text { 2. 'Two officers on a bike went over me } \\
\text { and Saeed. My head broke open and my } \\
\text { stomach was injured and my leg, I } \\
\text { couldn't walk. Hamid Alipoor held on by } \\
\text { grabbing under my arms, he was trying to } \\
\text { take me away. I said, "Saeed!” He said, } \\
\text { "What are you going to do with his } \\
\text { body?"' }\end{array}$ & $\begin{array}{l}\text { 2. 'The posters we were given to distribute } \\
\text { after the election was to cause people to } \\
\text { rise against and oppose the election results. } \\
\text { I escaped out of fear. The street had CCTV } \\
\text { cameras but the Home Office says that it is } \\
\text { not logical.' }\end{array}$ \\
\hline $\begin{array}{l}\text { 3. 'The first lorry in Turkey had an } \\
\text { Iranian driver. After three to four days, } \\
\text { lorries would change over. They had } \\
\text { made a hidden cubicle for me on the back } \\
\text { of the lorry; it was only big enough so } \\
\text { that I could sleep in it. The cubicle's door } \\
\text { was always shut. It was the second lorry } \\
\text { with a foreign driver that gave me the } \\
\text { aluminium-looking sheet to avoid the }\end{array}$ & $\begin{array}{l}\text { 3. 'It was from Iran to Turkey, [travelling] } \\
\text { with herds and then the journey continued } \\
\text { on a lorry. They took me somewhere and } \\
\text { told me that this is France. I then was in a } \\
\text { house for two months. The lorry was a } \\
\text { refrigerated truck; I got on the lorry at } 12 \\
\text { and got off it at } 12 \text { the following day, a } 24 \text { - } \\
\text { hour journey in that lorry.' }\end{array}$ \\
\hline
\end{tabular}




\begin{tabular}{|l|l|}
\hline $\begin{array}{l}\text { human detector device. The third lorry } \\
\text { boarded me and brought me to France or }\end{array}$ & \\
Italy - I don't know. I was dropped at a \\
forest and was handed over to a man. The & \\
lorry had parked on a road in the middle & \\
of woods. When the fourth lorry came, the & \\
driver opened the shutter. I saw that he & $\begin{array}{l}\text { had stored apples in it. This fourth lorry } \\
\text { was a refrigerated truck with apples } \\
\text { stacked up to its roof. [At this point } \\
\text { Bahram demonstrated how he lay on top } \\
\text { of the apples.] I was lying down like this } \\
\text { for } 14 \text { hours and this [hook] kept poking } \\
\text { into my back. It was very cold in there. } \\
\text { When the refrigerator began to work and } \\
\text { the temperature plunged, I thought I will } \\
\text { die. The temperature was } 4 \text { degrees and } \\
\text { there were } 10 \text { minutes of absolute cold } \\
\text { and then it would go off for } 5 \text { minutes.' }\end{array}$
\end{tabular}

Bahram has a clear storyline and elaborates it, giving very precise and detailed descriptions of events. He depicts his experiences vividly, using meticulous details, and invites the observer to watch, hear, and feel it with him. He provides an evocative account of tending to his dying friend, Saeed. This enables the listener to share the moment and creates empathy.

My friend was right next to me on my right-hand side [meticulous detail], called Saeed. I saw him fall down. He was married with one child; he was one of my relatives. I went over to him and held his head up and I could hear him gasping for breath [vivid sensory detail], his last breath. I didn't leave him. Saeed was in my arms [invites the observer to imagine].

It is evident that Bahram possesses the testimonial style favoured by the UKVI; in fact, his style seems to go beyond the recommended criteria of testimony in asylum claims. Pouya's 
narration, on the other hand, suffers from a twofold hindrance. First, he lacks a storyline that acts as a framework for his narration. The data from his initial FANI interview suggests that he is not fully aware of the reasons for the persecution he fears. As a result of his apparent lack of awareness of the reasons, he is unable to present a chronological and coherent account of events leading to his asylum claim. Secondly, while lacking a purposeful storyline, he fails to provide details about the relevant facts of his claim, which suggests he may not know what these facts are. There are pockets of detailed information in his narration, for instance, about his parents' bungalow and the width of the walls (see table 4, points 1 and 2), but they do not relate directly to his claim. His inability to follow the preferred style of testimony may stem from his unawareness of the significance of certain events: 'often the applicant himself may not be aware of the reasons for the persecution feared' ${ }^{85}$

\subsubsection{Anticipating the line of questioning}

Table 6 below demonstrates the men's ability to pre-empt questions that might be put to them, and to fill in any gaps in their account that might potentially be identified as problematic.

Table 6. Anticipating the line of questioning as an indicator of credibility

\begin{tabular}{|c|c|}
\hline Bahram & Pouya \\
\hline $\begin{array}{l}\text { 1. 'At last he said to me, "You stay here". It } \\
\text { was in street Z and street Q; he left me in a } \\
\text { dark alley. By now it was dark, as they had } \\
\text { continued chasing demonstrators well into } \\
\text { darkness. When Hamid Alipoor returned, } \\
\text { he said, "Both of them have been caught } \\
\text { with your car and everything in it"'. }\end{array}$ & $\begin{array}{l}\text { 1. 'The issue was that I was given the task } \\
\text { to collect and deliver posters in support of } \\
\text { the green movement from city A to city B } \\
\text { on the day of the election and the day after } \\
\text { the election. He [The Home Office } \\
\text { caseworker ] asked me, "What is the } \\
\text { distance between city A and city B?" I said, } \\
\text { "Three hours". But I could drive there in an } \\
\text { hour and a half; I don't know why I said } \\
\text { three hours. It is about } 170 \text { kilometres. I } \\
\text { told the caseworker that I don't know }\end{array}$ \\
\hline
\end{tabular}

85 UNHCR Handbook (n 5) para 66. 


\begin{tabular}{|c|c|}
\hline & English and I am shocked.' \\
\hline $\begin{array}{l}\text { 2. 'My sister's brother-in-law took us to } \\
\text { his uncle's house. We slept there. At } 8.30 \\
\text { or 9am, we woke up. I saw [that] my sister } \\
\text { had come in with tearful eyes. She said, } \\
\text { "They have raided our parents' house } \\
\text { (where I lived) and have thrown } \\
\text { everything in the yard of the house; they } \\
\text { pushed our mother". My mum is } 65 \text { and } \\
\text { they had pushed her around. Why did they } \\
\text { raid the house? Because my car had } \\
\text { revealed everything about me, like my car } \\
\text { details that had my name and address.' }\end{array}$ & $\begin{array}{l}\text { 2. 'The Home Office caseworker asked me } \\
\text { many questions: "What were you doing in } \\
\text { city A for } 6 \text { hours?" I told them that I was } \\
\text { washing my car's windows, repairing the } \\
\text { punctured tyre, and we ate. The Home } \\
\text { Office caseworker said that the first time } \\
\text { you spent a long time in city A [ } 6 \text { hours]. } \\
\text { But the first time in city A, things were not } \\
\text { as secretive as they werebefore the } \\
\text { election and its disputed results, so it was } \\
\text { not illegal. However, the second trip [after } \\
\text { the election] to city A was very short as we } \\
\text { were worried to be caught, and we wanted } \\
\text { to return as soon as possible.' }\end{array}$ \\
\hline
\end{tabular}

This table illustrates the interviewees' relative skills in anticipating areas of potential doubt in the mind of the examiner that might affect their credibility, and shows their ability to address these potential difficulties. Excerpt 1 from Bahram shows how he pre-empts a potential gap in his account. He quotes a friend telling him that two of their associates 'have been caught with [his] car and everything in it'. By doing this, Bahram implies that documents in his car, including his driver's licence, led the authorities to find his identity and home address. On the other hand, excerpt 1 from Pouya suggests that he was overwhelmed by pressure in the course of his interview with the UK caseworker. Pouya is also disappointed by his own performance; he does not know why he miscalculated the time that it took him to drive between the two destinations.

There has been little empirical research on the ways in which asylum seekers comprehend questions put to them by examiners and, in return, respond. This aspect of intercultural communication is distinct from the type of language barriers normally experienced in expressing oneself in another language. It is not related to a poor command of the English language, for instance. The communication problem in this respect stems from the applicant's ability (or inability) to appreciate and assess the nuances and subtext of the 
examiner's line of questioning. ${ }^{86}$ A lack of awareness means that an applicant may not be able to anticipate whether a response will be favourable to his or her claim. This may be extremely damaging and lead to the refusal of a claim. In other words, providing a successful testimony at the substantive interview entails accurately following the examiner's line of enquiry - more precisely, being able to deduce the suppositions and expectations underpinning the line of questioning.

In excerpt 1 in table 6, Bahram volunteers an explanation about the darkness when pursued by the authorities in the aftermath of a street demonstration. He identifies a potential gap in his narrative and addresses it, explaining that the chase started in daylight but had lasted long enough for it to become dark. In this way, he reminds the interviewer about the long duration of the chase by the security forces. This also highlights the possibility that Bahram believes this episode will help to emphasize the seriousness of the danger he faced from the authorities. More substantially, in saying that the authorities had taken taken his car, he pre-empts a potential question about why the authorities raided his house or how they knew where he lived. The fact that his car had been taken can then be used to explain how the security forces were able to identify him and subsequently raid his home. Bahram's interview data illustrates his awareness of those potential questions, as he explains: 'my car had revealed everything about me, my car details had my name and address. My driver's licence was in my taxi'. Before any inconsistency hypothesis can be formed, Bahram volunteers information that makes his account of events more consistent and more credible.

By contrast, Pouya does not seem to be aware of the importance of anticipating the examiner's line of enquiry and has many gaps in his story. He recollects his unsuccessful encounter with the examiner regarding the distance and time. At the time of the interview, he admittedly fails to provide a convincing response to address any inconsistencies that the examiner identified regarding the information in the two extracts in table 6 .

It can be argued that in an adversarial setting, the parties are at least aware of each other's line of questioning and can knowingly defend and counteract the arguments. By contrast, during an interview in the course of an asylum claim, the interviewing official forms a line of questioning which is not revealed to the applicant. All the questioning then leads towards proving the interviewer's hypothesis, while the applicant remains unaware of the

86 Jenny Thomas, Meaning in Interaction: An Introduction to Pragmatics (Longman 1995). 
direction he or she has taken with the questioning. ${ }^{87}$

According to Popovic, an applicant for refugee status must provide a statement with few generalizations, gaps, or distortions, which corresponds to the hypothesis formed in the mind of the examiner, in order to prove the claim. ${ }^{88}$ The 'hypotheses inside the investigator's mind' could mean a view has been formed of the applicant's claim prior to and during the asylum interview. These hypotheses are formed on the basis of information available to the examiner about the country and nationality of the applicant, in addition to perceived inconsistencies identified during the interview. These formed hypotheses are not revealed to applicants, hence they resort to describing their claim in a way that they think the examiner is inclined to accept as genuine. Popovic draws an analogy between the above practice and 'an adversarial trial in an inquisitorial setting' ${ }^{89}$ In this respect, the substantive asylum interview is, therefore, not only an opportunity for the asylum seeker to give reasons for claiming asylum, but also for officials to examine and potentially disprove the claim. As Barsky argues, an assessment of the applicant's credibility is more about the applicant's ability to sift through his or her experiences for appropriate selection. The analysis of the data in this study

87 Another example of gaps in Pouya's account filled by the official was obtained from the audio recording of his substantive interview. At times, the official asked questions, with the next possible question in mind, to identify prospective irrationality and inconsistencies in Pouya's answers. For instance, Pouya was pressed to estimate the number of people in the crowd during a mass demonstration at which he claimed to be present. When unable to provide an estimate, the official persistently pressed him with suggestions: 'Many?' or 'A lot?’ Pouya eventually accepted this inference and confirmed that there were 'a lot of people'. He was then confronted by the next question: 'How could you be recognized in the middle of a lot of people?' This was in the context of his claim that Iranian authorities had identified him at the demonstration and the official's attempt to undermine this claim by focusing on the fact that there were too many other people present for him to be singled out and recognized. The official may have concluded, therefore, that there was no risk if Pouya were returned to Iran, which may have contributed to the refusal of his asylum claim.

88 Aleksandra Popovic, 'Evidentiary Assessment and Non-Refoulement: Insights from Criminal Procedure' in Gregor Noll (ed), Proof, Evidentiary Assessment and Credibility in Asylum Procedures (Martinus Nijhoff Publishers 2005) 48.

89 ibid. 
suggests some possible reasons for the different outcomes for two such similar men, where Bahram was granted refugee status and Pouya’s claim was refused.

\section{CONCLUSION}

When asylum applicants present their claims, they use different styles of narration. As demonstrated in the analysis of the empirical data in this study, some applicants have a distinct advantage because they are able to present their claims in the prescribed manner. This article began by identifying and analysing some key guidelines produced by UNHCR regarding an applicant's 'non-duty' to analyse his or her case, and his or her shared duty with the examiner to establish the relevant facts of the claim. It then highlighted and examined the UKVI's preferred mode of presentation of a claim by reference to the API. Equipped with these legal and procedural frameworks, the article drew on a range of disciplines to anchor the analysis of empirical data. Although the two men studied were very similar in terms of the variables that could influence the outcome of their asylum claims, personal experience and psycholinguistic differences may reasonably have contributed to dissimilar testimonial styles and different outcomes. Despite earlier research suggesting that class and education are affective factors in the way testimonies are presented, ${ }^{90}$ they did not appear to be relevant here, since the men had similar backgrounds and limited schooling.

Despite their similarities, the accounts of Bahram and Pouya revealed remarkable differences in the style and content of their narratives. Bahram delivered an account that was chronological, detailed, and coherent. He appeared to have a more highly developed emotional intelligence, whereby he was able to grasp more than the semantic meaning of the questions asked. He also appeared able to read the subtext and anticipate the line of questioning in a way that was likely to meet an examiner's expectations.

Pouya, by contrast, did not seem to be aware of the importance of consistent chronology and of providing a detailed account. His difficulties highlighted the potential procedural unfairness involved in leaving applicants to their own devices, when, in fact, according to the UNHCR Handbook, it is not their duty to analyse their claims to the extent

90 Conley, O’Barr, and Lind (n 29) 1380. The findings 'revealed that witnesses of low social status the poor and uneducated - were most likely to use' a 'powerless' speech style which contributed to adverse credibility findings in respect of witnesses by the jury. 
that they must identify the reasons for persecution in detail. The UKVI instruction is weighted against applicants who lack these favoured skills. The findings of this study therefore challenge the fairness of applying a rigid set of criteria to unwitting applicants.

Another feature of Pouya's account was that he appeared to be unable to identify the facts that were relevant to the story of his asylum claim. He was a prime example of someone who has difficulties in sifting through his past experiences to communicate the elements most central to his story of asylum. By providing seemingly random information and being unable to present relevant material facts, he reduced his chances of presenting his past experiences in accordance with the required credibility indicators.

Since an applicant needs to know or understand what is required in detail before he or she can provide an acceptable account, any requirement of being able to identify and communicate the most relevant experiences, facts, and evidence is, therefore, unreasonable. Furthermore, in light of Pouya's inability to comprehend what was required of him, the duty of decision makers, particularly towards applicants in situations similar to Pouya's, must become more significant.

In practice, successfully fulfilling the responsibility of relaying the relevant and material facts to the examiner will depend on whether an applicant has the necessary skills and background knowledge. This article argues that unless there is an adept tendency to present a chronological, detailed, and coherent account, then the expectation of such an account from each and every asylum seeker is unreasonable and unfair. This is particularly true given that at no point during Home Office assessment of claims are the expected criteria (logical chronology, sufficiency of detail, and coherence) communicated to applicants for refugee status. As the analysis of Bahram and Pouya's different presentational skills shows, differences in testimonial style can - and do - affect findings of credibility, and thus influence the success - or otherwise - of asylum claims. In the context of the refugee status determination process, the difference between favoured and unfavoured testimonial styles, and between credible and non-credible applicants, can potentially be a matter of life or death, or liberty or imprisonment.

The procedural safeguards set forth in civil and criminal trials are included in two articles of the European Convention on Human Rights, article 6 and article 13, which 
establish 'the right to a fair trial' and 'the right to an effective remedy' respectively. ${ }^{96}$ The standards of the procedure in immigration and asylum cases are not defined by article 6 , since in the case of Maaouia $v$ France, ${ }^{97}$ the European Court of Human Rights held that article 6 is not applicable to asylum and immigration proceedings. 'Decisions regarding the entry, stay and deportation of aliens do not concern the determination of an applicant's civil rights or obligations or of a criminal charge against him, within the meaning of article 6 (1) of the Convention' ${ }^{98}$ In the absence of the procedural safeguards that article 6 guarantees in civil and criminal trials and the anomaly highlighted regarding the UNHCR Handbook's emphasis on shared responsibility, the asylum process at the stage when the Home Office conducts and decides on asylum claims represents procedural unfairness.

Applicants for refugee status must have an understanding of the process and procedure in order to perform successfully. An awareness of the meaning of persecution and credibility issues would be advantageous. More specifically, in order to avoid inconsistency in an account that contributes to adverse credibility findings, an applicant ought to be able to minimize potential gaps and contradictions. In this context, while examiners may request clarification or additional detail, an ability to anticipate the line of questioning may also prove beneficial.

In an adversarial court setting, a judge and/or legal representative can help to safeguard individuals against leading and/or trick questions. Equally, the hypothesis formed in the mind of the opposing legal representative is revealed to witnesses and the defendant's

96 Council of Europe, European Convention for the Protection of Human Rights and Fundamental Freedoms, as amended by Protocols Nos 11 and 14, 4 November 1950, ETS 5 <http://www.refworld.org/docid/3ae6b3b04.html> accessed 4 December 2016.

97 Maaouia v France, App No 39652/98 (ECtHR, 5 October 2000).

98 'Standards of the Provisional Protection against Expulsion', speech delivered by Dr Chlebny, judge of the Supreme Administrative Court, Poland, at a seminar organized on the occasion of the publication of the Handbook on European Law relating to Asylum, Borders and Immigration, (Strasbourg, 11 June 2013) 4 <http://fra.europa.eu/sites/default/files/jacek-chlebny-speechstrasbourg-11-june-2013.pdf> accessed December 2016. See also Marie-Bénédicte Dembour, When Humans Become Migrants: Study of the European Court of Human Rights with an InterAmerican Counterpoint (OUP 2015) 224. 
legal representative. However, in the asylum process, the examiner simultaneously assumes the roles of adversary, inquisitor, and judge of the claim. Given the different levels of ability in the testimonial styles and presentational skills of asylum applicants, it is reasonable to expect that an interview as significant as a substantive asylum interview would involve some level of prior familiarization. ${ }^{99}$

This article's comparative analysis of the presentational styles of two asylum seekers has illustrated the fact that two people with the same nationality, background, and experiences may express key aspects of their life stories that are pertinent to their claims in very different ways. Their styles may or may not accord with that preferred by authorities and deemed to be credible. The article argues that such differences may lead to different outcomes in the asylum process. This finding represents an important contribution to the literature on refugee status determination, since it documents a reality regarding narrative styles related to asylum claims that has been known implicitly for some time. The results offer a strong rationale for expanding legal aid in asylum cases in order to close the gap between the presentational styles of individual asylum seekers. It is also recommended that the duty of caseworkers and adjudicators should extend to ensuring that questions are asked in an appropriate way, and that applicants are given the support they need to prepare for the challenges they will face in substantive interviews.

This article has been based on two case studies which produced very rich, in-depth data relating to the interaction of asylum seekers and the legal rules they face when presenting their asylum claims to the appropriate authorities. However, it is acknowledged that the study was conducted by a single researcher, which may lead to a charge of subjectivity. While the conclusions that can be drawn from this research about other asylum seekers going through the asylum process are limited in terms of the generalizations that can be drawn, this work points to the need for a larger study in order to generate further data, designed in such a way as to make generalized conclusions possible. This would allow recommendations to be made for reform of asylum procedures in the UK and other States making decisions about individuals in need of protection from persecution and other human rights abuses.

$99 \quad R$ v Momodou [2005] EWCA Crim 177. See also Adrian Keane and Paul McKeown, The Modern Law of Evidence (OUP 2014) 166. 
(The Tale of Two Men: Testimonial Styles in Asylum Claims) 